\title{
Transforming an \\ Educational Community in \\ Guatemala Using the Plan \\ Do Study Act Cycle ${ }^{1}$
}

Transformación de una Comunidad

Educativa en Guatemala utilizando el

Ciclo Planificar, Estudiar y Actuar

Mayra C Daniel, Teresa Wasonga, and Ximena Burgin²

Northern Illinois University, USA

${ }^{1}$ Received: February 1st 2021/ Accepted: October 15th 2021

2 mayra.daniel@gmail.com; twasonga@niu.edu; xrecald1@niu.edu 


\section{Abstract}

This case study with educators from a school in an urban low socioeconomic neighborhood near Guatemala City, Guatemala, explored the effectiveness of the Plan, Do, Study, Act cycle (PDSA) to guide teachers' professional development at a Pre-K-K public school (Langley, 2009). This three-year study focused on developing teacher leaders and researchers through selfreflective accountability. Findings documented institutional problems requiring immediate and long-term attention and ways to involve families in extending literacy instruction at school to the home front. Study results highlight the need for effective and empowering literacy methods to be used in Guatemala and suggest the country's teachers wish to support students' critical thinking and create democratic classrooms.

Keywords: Plan Do Study, Act Cycle; School Improvement; Guatemalan Education;

Teachers as leaders

\section{Resumen}

Este artículo documenta un plan de desarrollo profesional ofrecido a docentes de una escuela en Guatemala de niveles pre-K al K. Este estudio apoyó la contabilidad individual del docente que interpreta el currículo considerando el contexto social. El ciclo Planear, Experimentar, Estudiar y Actuar, involucró a los participantes a colaborar. Los resultados señalaron problemas institucionales y sociales que requieren atención. Se identificaron metas para involucrar a familias a enlazar los temas del currículo a los de la vida cotidiana. Las familias reconocieron su rol en el aprendizaje de sus hijos. Los docentes adaptaron los estándares del Ministerio de Educación para crear aulas democráticas y apoyar el pensamiento crítico.

Palabras Claves: Ciclo Planear Experimentar Estudiar y Actuar; Mejora Escolar; Educación en Guatemala; Desarrollo Profesional

\section{Resumo}

Este artigo documenta um plano de desenvolvimento profissional oferecido a professores de uma escola na Guatemala de níveis pré-K ao K. Este estudo apoiou a contabilidade individual do professor que interpreta o currículo considerando o contexto social. O ciclo Planejar, Experimentar, Estudar e Atuar envolveu os participantes a colaborar. Os resultados sinalaram problemas institucionais e sociais que requerem atenção. Identificaram-se metas para envolver a famílias a enlaçar os assuntos do currículo aos da vida cotidiana. Famílias reconheceram seu papel no aprendizado de seus filhos. Os professores adaptaram os padrões do Ministério de Educação para criar aulas democráticas e apoiar o pensamento crítico.

Palavra chave: Ciclo Planejar, Experimentar Estudar e Atuar; Melhora Escolar; Educação na Guatemala; Desenvolvimento Profissional 


\section{Introduction}

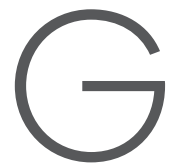

uatemalan educators strive to follow the government's mandated curriculum, and they ask that professional development (PD) provide an implementable instructional plan, and a sustainable vision for equity and critical pedagogy (Faundez, 2001; Freire, 2002; Giroux \& Robbins, 2006; Hawkins \& Norton, 2009). An ongoing problem in Guatemalan education is that PD models have not been developed in consultation with teachers (Guadarrama, 2013). Research documents the need for PD to focus on building teacher leaders able to design effective literacy curricula (Bastos, 2012). Researchers have stressed the need to give teachers resources for their classrooms, and the training that will empower them to lead (Daniel, 2010; Taylor, 2013; Daniel, Mondschein \& de Palomo, 2014; Orozco \&Valdivia, 2017). Efforts by the Guatemalan Ministry of Education (MINEDUC) have neither helped teachers adapt the National Curriculum standards to their school context (Bastos \& Brett, 2010), nor adequately funded curricular resources (Cojti, 2005; AVANCSO, 2008; Camus, 2010).

\section{Theoretical Framework}

This three-year study engaged literacy educators to explore ways to liberate learners and their families from an educational system that is delimited by an insufficient focus on critical pedagogy (Norton \& Toohey, 2002; Aliakbari \& Faraji, 2011; Coney, 2016区. This study aligns to Freire's (2002) sociocultural learning theory, and Gay's (2010) philosophy of culturally responsive pedagogy. Critical pedagogy supports Freire's (2002) premises that the rights of citizenship begin with equitable access in schooling. In this research, conscientization is defined as a commitment to a critical pedagogy of practice that is born in the heart of the individual, and is participatory, critical, democratic, dialogic, pluricultural, and based on inter and intrapersonal reflection (Vygotsky, 2002; Gathercoal, 2004; Norton \&Toohey, 2004; Gay, 2010; Coney, 2016; Daniel, Riley \& Kruger, 2017). This research engaged educators in designing empowering models of instruction for Guatemala's sociocultural context (Verhoeven \& Durgunoglu, 1998; Vygotsky, 2002; González, Moll \& Amanti, 2005; Orozco \&Valdivia, 2017). When Freire discussed anger and its constructive use, he highlighted that it can serve '... as a legitimate motivational foundation' (Aronowitz et al., p 45) for liberatory learning. We posited that it is key to find ways for teachers in Guatemala to redirect their anger towards MINEDUC's hegemonic structures.

The theoretical framework that guided this study was implemented with teacher participants using the Plan, Do, Study, Act (PDSA) model (Bryk, 2015; Bryk 
et al., 2016). PD delivered to educators from one Guatemalan school supported the development of teacher leaders with a focus on increasing accountability from the ground-up, and promoting socio-culturally appropriate instruction (Lantolf et al., 2015). PDSA improves the schoolhouse because it is a vehicle for planning effective instructional goals, selecting appropriate strategies to do (practice the skill), study and reflect upon progress, and make necessary changes or act on the cycle information prior to repeating the cycle (Bryk et al., 2016). Long-term PD guided by the PDSA cycle revolutionizes stakeholders to interact positively in their goal setting. The cycle changes social practices because its success depends on inter-personal communication that places equal value on all participants' contributions. The cycle supports teachers' natural inclination to be methodical investigators who document the recurrent themes in what they experience, and observe in their work (Bryk, 2015). PDSA aligns to Bronfenbrenner's ecological theory of development which posits that academic success requires an educational system that considers the social environments where a learner interacts and engages in a continuous process of developing and supporting his/her identity (Bronfenbrenner \& Morris ,2006). This work examined how application of PDSA with teachers from one Guatemalan school might offer a pathway to engage educators in collaborative inquiry, and support their long-term commitment to students' academic achievement.

\section{The Rationale Underlying Educational Transformations Through the PDSA Cycle}

The PDSA cycle has gained popularity within the past 10 years as a model for inquiry and continuous improvement in education (Shakman et al., 2017). The success of PDSA lies in its reliance on observational and experiential input from group members who collaborate to improve a community's educational system (Bryk, 2015). According to Cohen-Vogel et al. (2016), the PDSA cycle tests possible solutions to educational problems by contextually considering the effect of an intervention. The methodological implementation of the steps provides information to determine achievement of the desired changes (Russell et al., 2017). The model had its origins in healthcare where success is a matter of life and death. It provided reflective accountability because the thermometer that measured its success was the initiative and commitment of the individuals involved in its implementation, and the effects of their leadership skills on group participants. In education, PDSA can be used by a wide variety of stakeholders to identify learners' academic and affective needs, to reflect on actions to be taken, to streamline processes through collective inquiry, and to more effectively implement instructional strategies in classrooms (Langley et al., 2009). Applying the PDSA model in education may save the lives of learners whose everyday inter-personal interactions may be with individuals who may not demonstrate respect for diversity, creativity and independent thinking. Teachers knowledgeable of PDSA 
processes change their classroom and ensure all students grasp that their voices and thoughts are valid. PDSA provides educators recursive opportunities to arrive at answers to problems more expediently than if they worked individually or waited for the assigned system's leaders to act (Bryk, 2015; Bryk et al., 2016). The model emphasizes collaborative decision-making and teacher advocacy, which could prove to efficiently build on Guatemalan educators' strengths. In this study the beginning of the inquiry-based PDSA cycle was informed by questioning using the 5Whys technique (Serrat, 2009). The teachers engaged in a one-on-one conversation with Mayra (researcher one) about the overall educational challenges in Guatemala and then participated in a focus group after conducting an ethnography. During the focus group the repetition of the word Why helped the teachers delve into the problems that recur in the school community more deeply. The technique served to unveil the root cause of the issues and the circumstances surrounding the recurrence of the problems to find possible solutions (Hibino et al. 2018). This approach to encourage questioning was an appropriate choice to engage Guatemalans, because they form a cultural group whose inter-personal interactions abound with courtesy and respect. The 5Whys provided a vehicle to systematically question issues in the Guatemalan educational system.

PDSA requires working from participants' knowledge of the problems to be solved to their predictions of how to move from frustration and anger, to developing situated theory applications that achieve positive changes (Langley et al. ,2009). The PDSA cycle always seeks to identify a path to achieve the goal that will lead to improvement of a situation, and provide an evaluative method to document the level of improvement reached. Implementation of PDSA is a community affair. Once teachers experience problem solving through PDSA, they are able to teach its application to students who will then identify ways to solve problems in classrooms, and in their communities and homes. Learners of all ages can master the PDSA cycle because its design reflects human beings' needs for inquiry, and supports engagement focused on affective and basic survival needs. The model helps students identify effective learning goals, select appropriate strategies to practice the skill that is the focus of the teacher's lesson, study and reflect upon their own progress, and make necessary changes to apply the information gathered before repeating the cycle. Students and teachers apply PDSA when they brainstorm ways to solve problems within a community that works together, and rejoices in its successes. Together with committed teachers, learners explore problems, and posit solutions in classroom conversations that revolve around stories or current events in their lives. In this study, teachers observed and examined young children's responses to decide when it was time to proceed to a different step of the PDSA cycle. This project examined changes at Escuela Villa Hermosa $(E V H)(\mathrm{a}$ pseudonym) due to implementation of the PDSA cycle. In this collaborative process to enhance literacy, the participants reflected on areas for improvement, educational practices, and interactions with administrators and parents to benefit the students. 
Figure 1. Applied PDSA Processes

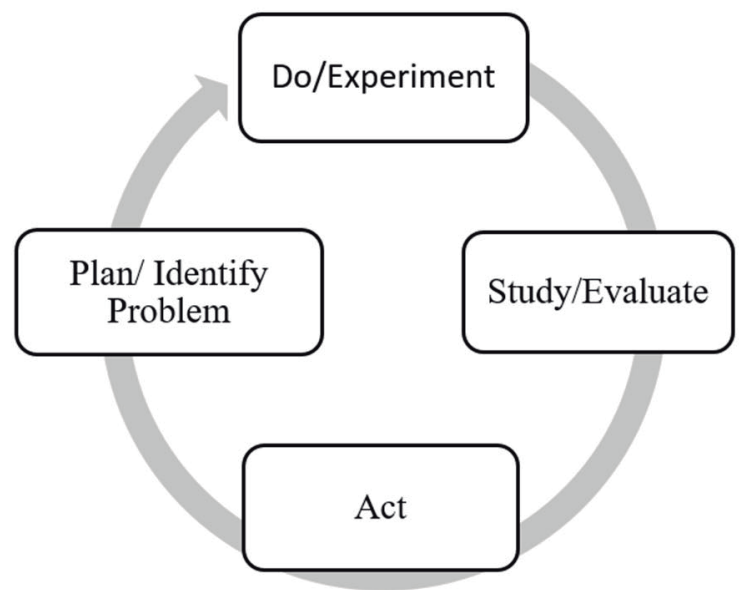

\section{Methodology}

This case study (Stake, 2000) focused on the teaching and learning environment at $E V H$. Data were collected in three phases over a three-year period. Phase one was the exploration and documentation of community needs. These included the academic and affective needs of the children who reside in the EVH community, as documented in conversations with families and in observations conducted by the teachers. Phase two involved the teachers in a focus group where they had the opportunity to share their interpretation of the ethnographic data that they gathered during phase one. Phase three engaged the teachers in weekly PD envisioned through the implementation of a PDSA led inquiry that had at its goal designing a contextually appropriate curriculum and led the teachers to write storybooks for their classrooms. The qualitative data were recorded in Spanish and analyzed utilizing a constant comparison technique (Glaser \& Strauss, 1967). The process allowed for an iterative development of codes by comparing the new data to existing data processed (Leech \& Onwuegbuzie, 2007). The following questions guided this study: 1 . What changes are needed at EVH?, 2. How will appropriate changes be prioritized and implemented?, 3. How did participants change their educational philosophies due to participation in this study? 


\section{Participants and Site of Research}

This research was conducted at the $E V H$, a school in an urban low socioeconomic neighborhood in a city of about 140, 000 located near Guatemala's capital city. In the park about 30 feet from the school, one can observe drug selling activity among single males who sit at picnic tables buying and selling products in small bags. Study participants included the entire faculty of the school; eight pre-K-K teachers and the school principal. The teachers, all trained in Guatemala's Normal Schools, ranged in age from 23 to 47, with the principal being the eldest. The student population was 63 students.

\section{Phase 1: Exploration and Documentation of Community Needs}

This phase began with informal conversations between Betty (a pseudonym), the new principal at $E V H$, and Luci (a pseudonym) the principal of the private school where Betty previously taught. Before Betty accepted the principalship, she realized that the learning environment at $E V H$ was not what she had helped to design in her previous position. Betty, with Luci's help, came up with a plan to reimagine and recreate her new school. Their vision was based on what they had experienced at Escuela José Antonio (JA) (a pseudonym), a thriving community of educator-advocates. Conversations that followed between two teachers at $E V H$ and their new principal were the first step to putting the plan into place. These led to one-on-one interviews with the entire faculty and the principal. As the interviews took place, data began to reflect concerns.

The developing vision of the nine educators who composed the faculty led them to carry out an ethnography in the EVH community. They reached out to parents and explored the community. Observations in walks around the neighborhood and data from interviews and conversations with families, served the teachers to draw a picture of the environment surrounding the school, the realities of the children's lives, and the affective and instructional needs of learners growing up in a high crime neighborhood. After completion of the ethnography and examination of the data, the teachers studied the problems that were identified and reflected on what they might do next. They decided that tasks for the next phase of this study would address teachers' need for the adequate resources that would allow them to plan and deliver culturally responsive instruction.

\section{Phase 2: Focus Group}

The Five Whys (5Ws) inquiry method was used for a needs assessment conducted with the teachers following the ethnography (Serrat,2009). Their ideas needed to be clarified and organized, thus the 5Ws served as an initial and ongoing questioning 
technique. The 5Ws were the scaffold to outline needs and prepare the teachers to engage in the steps of the PDSA cycle. Group participants answered five questions with the objective of stating problems accurately and completely, to do so honestly with the knowledge that their identity would be kept anonymous, and to be fully committed to resolving the problems (Serrat, 2009). The process of posing the first $5 \mathrm{~W}$ s questions begins when researchers gather a research team or conduct one on one interviews with community members. As participants are identified the goal of establishing the prior knowledge needed to begin the questioning sequence begins. The inter-personal interactions with possible participants contribute to the researchers' understanding of the individual teachers and begin to reveal their attitudes toward their responsibilities as educators of Guatemala. Informed researchers are able to ask an appropriate first why question because they have some knowledge of the problems that need to be addressed. Answers are documented on a board that is visible to participants, who then use the information as a scaffold to formulate replies to remaining $5 \mathrm{~W}$ questions.

In this research the first $5 \mathrm{~W}$ question asked after the initial exploration of the problems at EVH community was: What information did the ethnography reveal and why is that? The four follow up questions repeated the inquiry by asking: Why is that? It was anticipated that responses would document obstacles to learning unique to the EVH community. Challenges might relate to the fears the learners face on a daily basis, and to how these fears might delimit the learning. The hope was that answers would highlight curricular limitations, and support teachers' sharing of remaining challenges. At the conclusion of phase 2, the objective was for the teachers be able to state their advocacy abilities, and how they would deliver an empowering curriculum that went beyond MINEDUC's curriculum.

\section{Phase 3: Weekly PD Guided by PDSA}

The teachers at EVH participated in PD one full day a week over a three-year period. The PD was delivered by the joint team of Luci, the principal at $J A$, and Marta, one of her teachers (a pseudonym), during the first three months of the project. After this Marta was responsible for the PD, with Luci checking in once a month. All PD was delivered through a hands-on approach at the school. The teachers were not given materials to read prior to the PD because the trainers felt they would be more open to hands on training, modeling, and active discussion. The objectives of the PD were for the teachers to (1) experience working to design lessons in teams, (2) plan and deliver balanced literacy instruction using narratives that reflected their community, (3) increase parental involvement, and (4) begin to align the national curriculum to contextually congruent literacy lessons.

Tasks introduced and explored in the PD aimed to address the project's objectives one and two, thereby addressing lesson planning and critical thinking. The teachers 
brainstormed and collaborated on lessons to integrate critical thinking into skillbased instruction. Methods used to teach vocabulary aimed to help learners express their opinions. Literacy instruction modeled demonstrated that all five senses provide support for students' different learning styles. Discussions of the multiple intelligences were contrasted with conversations about learning styles in an effort to highlight that all children have ideas, and need the opportunities to feel safe to share these ideas. The trainers stressed process over product, when they showed participants how to work with some of the books that were used with learners at $J A$. Emphasis was placed on the anticipatory set, and on how chatting with children prior to or at the beginning of lessons will reveal their funds of knowledge. The teachers were encouraged to explore student groupings, and to experiment with heterogeneous models. In addition, discussions addressed components of lessons such as measurable objectives, planned questioning, tasks that stress process over product, and formative assessment.

Objective three involved planning PD for families, and envisioning what would ensure participation from parents, and help the teachers uncover familial issues that children find difficult to confront. Discussions emphasized that outreach to families begins at the schoolhouse door. Objective four was addressed as the PD focused extensively on the requirements of the national curriculum, and what teachers might do to adjust MINEDUC's scope and sequence to their community's needs. Using JA's bimonthly planning as a model, the teachers at $E V H$ worked to develop a method for planning ahead, and for selecting books and activities to support learners to become critical readers.

In order to stay on track, the PDSA recursive analytical cycle was used to guide all steps of the decision making in the PD. Through PDSA, after problems were identified, the educators decided on an efficient next step. Plausible actions were prioritized and followed by experimentation with the curriculum and outreach to parents. Next, stakeholders shared findings and analyzed the data gathered to establish if the solutions implemented worked well, or needed modification. As such, the cycle supported databased decision making (Bryk, 2016; 2015) because it assisted the teachers to consider the dynamic interplay between learners, their teachers, stakeholders beyond the school itself, and maintain a focus on culturally responsive curriculum development.

\section{Results}

Data suggest that participants uncovered many complexities in school improvement efforts. Participants documented problems requiring immediate and long-term attention in the school's physical plant, such as maintenance of existing buildings to financing the construction of a facility to shield stakeholders from inclement weather. In relationship to curricular needs, the educators from $E V H$ explored the need to 
address the appropriateness of available resources, and how to meet the government's curricular standards while supporting teachers in a socio-culturally focused, and consistent model of PD. The teachers went beyond preparing a list of needs or voicing their anger and angst. They demonstrated their commitment to advocacy, and to improving education in Guatemala's public schools. Without doubt, the teacher participants gained information throughout the three phases of the data collection. Three themes emerged from the data: (1) the need to remedy the condition of the existing school, (2) the learning issues of the students, and (3) steps that would lead to the implementation of needed changes.

\section{Theme 1: Condition of the Existing School}

When the teachers began analyzing and documenting the children's needs, their focus on improving literacy became clearer. They concluded that their students' affective needs were not being considered due to the condition of the existing school and the inadequate resources being used in literacy instruction. Therefore, rebuilding $E V H$ became the group's first priority. The teachers did not wait for resources from MINEDUC. They discussed what might be possible using the community's financial resources. They gathered funds to build a welcoming and efficient school. Their first goal was to teach in an environment where learners would feel safe, and to involve the parents in supporting the learning goals at $E V H$.

Modest buildings were erected as a result of fund raising led by the teachers. Students' families joined the fundraising effort and parents themselves reached out to community members for financial support. Many folks made conservative monetary contributions and/or donated building materials. A school site was identified where classrooms would be housed in small buildings. The community enthusiastically gave of their time and knowledge of carpentry, painting, and shared their building trade expertise. The result was a modest but improved school compound. The floors and the walls of the buildings were built of single sheets of raw wood and the tin roofs doubled as inside classroom ceilings. The colors of the buildings were selected for the purpose of creating an environment that placed young learners in a magical world using bright pink, light green, and a warm sunny tone. Outside walls were decorated with drawings of inspiring figures such as the Little Prince. Practical concerns led to one of the buildings housing a small kitchen that served to protect the cook from inclement weather. A room became a dedicated library and although it is small and has few holdings, it serves its purpose. 


\section{Theme 2: Literacy Learning Issues}

Besides the need to build a new school, the teachers compiled a list of community needs, and identified problems. At the top of the list was to eliminate the transmission model of education that is often the norm in Guatemala. The teachers agreed that modeling for learners how to think critically would help them generate ideas, and become invested in the learning. They knew that resolving their entire list of problems would take time and careful planning. They documented issues of hunger, poverty, and misspent money. Their list included the mismatch between the instructional methods used when the parents were students and still frequently used in Guatemala, in contrast to the balanced literacy approaches the teachers were learning in their PD. The teachers wanted to eliminate schooling that does not reflect societal needs in its curriculum, and thus makes little sense to the learners.

Data from the 5 Whys conversation documented recurring concerns in the teachers' observations: that children are afraid while in their homes at night, and that they are discouraged from talking to their families. The teachers repeatedly voiced the concerns evident in the following comments: 'How can they learn [the children] if they fear sharing their opinions?', We have to teach them to share their ideas', 'Parents need to know why we teach as we do'. 'We need to explain to the parents why our methods engage the children and why active learning is more effective, 'Families do not realize that young children learn by singing and dancing.

\section{Theme 3: Implementation of Changes}

The teachers' philosophies changed as they examined their observations, and proposed actions. They began to understand PDSA as a way to go beyond opinions, and subjective reactions. As they went through the steps of the cycle in each PD session, it became second nature for them to engage in joint reflection. Conversations focused on the planning, doing, studying and taking action recommended by the PDSA cycle were useful in identifying problems that required immediate attention. As the teachers gained clarity of how they might go about making changes, they planned a town hall meeting for the parents, and invited them to participate in PD. The teachers demonstrated how they taught the children, and the parents role played being the students. Giving the parents the opportunity to experience participatory learning was a path to justify the need for families to contribute their financial share, and back up the teachers' commitment and innovative curriculum. The teachers started to implement changes after selecting one problem to address at a time. They decided to bring parents together to share information, and to ask their support for the new instructional methods to be followed at home. The teachers gave immediate attention to identifying the most pressing problems when they brainstormed how to involve the families, and when they might plan PD to model their teaching for the parents. 
A problem that the teachers chose to address immediately was that families were sending snacks to school with the children that were not nutritious. There was no need for the parents to spend their money on sending sweet treats, since the government subsidizes a daily mid-morning snack. The funds could be better spent for children's books. They alerted the parents when they picked up their children about the government's funding for school snacks. After this, they identified the next step: a town hall meeting to earnestly seek monetary support from the parents. It was time to turn families' attention to strengthening the curriculum.

The town hall was a celebration of what had been accomplished, and a time for the teachers to share their dreams for the children. They introduced families to experiential methods of instruction. They inspired the parents with their enthusiasm, and with details of what they would do to raise the learners' academic achievement. They explained why 'Families must invest in their children both emotionally and financially' They discussed the reasons they were inspired to learn the methods being used at Escuela JA, and why they would improve the children's lives. EVH's teachers detailed how their time observing, and chatting, with the educators at $J A$, had made it possible for them to see what was possible. They shared what they had learned about planning balanced literacy lessons, and their belief that this could occur when student participation and parental involvement are part of the equation. They emphasized why parents were an essential part of the progress.

The teachers demonstrated their commitment to take risks with instructional methods. They detailed their new-found awareness of their own responsibility to anticipate what learners need to do, see, and hear as they learn. They shared their conviction that young children learn when the five senses are involved and why they had to provide opportunities for each and every learner to participate in classroom conversations that should be continued at home.

A recurrent theme in parental questions was how children could learn without sitting and quietly listening. A parent shared, 'At home my children jump, and they play, and they need to learn to behave because they are wild! They are so noisy when they are having fun'. Another parent's question was, 'How do you get children to listen when they are so loud!'. A third parent commented, 'I want my children to be respectful and well behaved. I don't know how your approaches work'. As the parents noted the teachers' enthusiasm and how this might support the learners' literacy, they asked for details. It became evident that one town hall meeting would not be sufficient to cover all that needed to be addressed. The teachers decided that the parents' questions had to be further addressed.

In their goal of breaking standing perceptions of schooling, and getting parents on board to not only support the new methods at the school, but to also follow the methods in their homes, the teachers realized the parents had to be privy to the benefits of the revolutionary way that instructional goals at $E V H$ were being set and met. At 
this point in time the parents were invited to PD sessions to explore books, just as their children were doing in their classrooms. The hands-on participation was planned so that parents could experience learning using all the senses.

Prior to the lessons, the teachers told the parents that they needed more books for their classrooms, and that the books had to be contextually sound if they were to make sense to the learners. When the teachers showed the parents the books that were used at $J A$, the parents began to understand the meaning of the words contextually sound. The parents began to grasp why the children should read books at school that reflected them and their community, and why they needed to have copies of the books to take home to share with their family. At the workshops the parents saw the teachers' commitment, and heard that families are responsible for the children's education. The parents were asked to help finance the printing of the books the teachers were writing, and to buy a cloth bag so the children could own and take home the books they read at school. Luci, the JA principal, shared copyright free access to the books she and her teachers had written so the books could be reproduced for the children at EVH. It was a win-win situation.

\section{Discussion}

The questioning, reflection and advocacy facilitated through the PDSA-based $\mathrm{PD}$ that led to changes in instruction at $E V H$ was powerful. At the end of the study, the teachers spoke expecting to be listened to, and they demanded respect and acknowledgement for their efforts. When the teachers spoke about the children and their literacy, high levels of satisfaction were evidenced such as 'Poverty can be transformed into riches'. As the teachers engaged students in dialogue, the children demonstrated their innate ability to ask high level questions, and to share ideas that evolved from their lived experiences and families' histories. Teachers from EVH narrowed the space between themselves and their students, because they nurtured transformative consciousness (Darder, 1998). In a climate of love the students were not perceived as the other but as co-learners freely engaged in discovering knowledge, and in working towards understanding themselves, and their role as citizens of their community (Aronowitz et al. 1998). No one at EVH felt silenced.

After the first year of the study, when learners went on to the primary school, the teachers' efforts were validated. At the same time, their frustrations with the Guatemalan educational system became evident again. The most alarming comment was stated by a teacher who shared that at the elementary school, inquiry is criticized. 'The teachers there think it a problem that the children ask questions and know too much'. Teacher 2 added: 'Would you believe that they discourage critical thinking?'. 
Teacher 3 said: 'They do not want the children to talk'. Teacher 3 noted: 'We offered to do workshops and share books, but when we tried to work together, they just sat there and did not participate'.

\section{Limitations}

Generalizability of this study's findings is limited to the community where this work was conducted. There are great variations in the way schooling is delivered in Guatemalan schools and in how teachers prepare lesson plans and select curriculum that adheres to MINEDUC's mandates. This study's participants composed an unusual group of educators because their school principal supported them in ways that led the teachers feel safe voicing their ideas with each other and helping the learners to express themselves. This is not the case in the majority of Guatemalan schools.

\section{Concluding Thoughts}

Educators in this study worked to meet high goals for their learners through balanced literacy practices guided by the recursive reflection that is the essence of the PDSA learning cycle (Langley et al., 2009). This research revealed the abilities and zeal of Guatemalan teachers to create a future of possibilities for the learners in their classrooms. This work suggests Guatemalan teachers can indeed reimagine paths for teaching and learning. The EVH faculty took action as they heeded their souls' call for change. They identified ways to advocate for their students going beyond the requirement of using texts supplied by MINEDUC. They learned how to make the curriculum meaningful for students' socio-cultural context. These educators decided to create democratic classroom environments (Langley et al., 2009). They chose to set aside resources that did not support culturally responsive pedagogy, and to go beyond the minimum requirements set by the government.

As the teachers participated in the PDSA processes, they gained confidence. The teachers saw children's enthusiasm in how the little ones offered their ideas and asked questions in class. The teachers proudly shared that every day the parents began asking to hear the songs the teachers had taught that day, and wanted to learn about the stories their children had read at school. Lina (a pseudonym) shared the philosophy that the teachers repeat to all who listen, and especially to the children. 'Your parents work in their jobs and at home. Children's work is to learn at school'. We admire the teachers in this study because they took a chance and devoted their time to learn without personal recompense. Perhaps this is the reason they were successful. 


\section{References}

Aliakbari, M. , \& Faraji, E. (2011). Basic principles of Critical Pedagogy. [Paper presentation]. 2nd International Conference on Humanities, Historical, and Social Sciences. IPEDR 17. Singapore: IACSIT Press.

Aronowitz, S., Clarke, P., Freire, P. (1998). Pedagogy of freedom: Ethics, democracy, and civic courage. Rowman \& Littlefield.

AVANCSO. 2008. Las políticas del reconocimiento. Una mirada al quehacer sobre racismo y discriminación en Guatemala. [Politics of recognition: A look at racism and discrimination in Guatemala]. Guatemala: AVANCSO.

Bastos, S. (2012). Multicultural projects in Guatemala: Identity tensions and everyday ideologies. Latin American and Caribbean Ethnic Studies, 7(2), 155-172.

Bastos, S., \& Brett, R. (Eds.) 2010. El movimiento maya de Guatemala en la década después de la paz. [The Mayan movement in Guatemala in the decade after peace]. Guatemala: F y G Editores.

Bronfenbrenner, U., \& Morris, P. (2006). The bioecological model of human development. In W. Damon \& R. M. Lerner (Eds.), Handbook of child psychology: Vol. 1. Theoretical models of human development (6th ed., pp. 793-828). Wiley.

Bryk, A, S., Gómez, L. M., Grunow, A. \& LeMahieu, P. (2016). Learning to improve: How America's schools can get better at getting better. Harvard, MA: Harvard Education Press.

Bryk, A. S. (2015). 2014 AERA distinguished lecture: Accelerating how we learn to improve. Educational Researcher, 44(9), 467-477.

Camus, M. (2010). La movilización indígena en Huehuetenango. [Indigenous movement in Huehuetenango]. In S. Bastos \& R. Brett (Eds.). El movimiento maya de Guatemala en la década después de la paz. [The Mayan movement in Guatemala in the post-peace decade] 267-312. Guatemala: F y G Editores.

Cohen-Vogel, L., Cannata, M., Rutledge, S. A., \& Socoll, A. R. (2016). A model of continuous improvement in high schools: A process for research, innovation design, implementation, and scale. Teachers College Record, 118(13), 1-26.

Cojtí, D. (2005). Runuk'ikRi K’ak’a Saqamaq’ pa Iximulew. Difícil transición al estado multinacional. El caso del estado monoétnico de Guatemala. [Difficult transition to a multi-national state: The case of Guatemala's one ethnic state]. Guatemala: Editorial Cholsamaj. 
Coney, L. (2016). The first step toward social justice: Teacher reflection. In C. Hastings \& L. Jacob (Eds.), The importance of social justice in English language teaching (pp. 11-23). TESOL Press.

Daniel, M., Riley, C., \& Kruger, T. (2017). Student-centered approaches for teaching social studies to English learners. In M. C. Daniel (Ed.), English learners at the top of the class: Reading and writing for authentic purposes (pp. 83-99). Lanham, MD: Rowman and Littlefield Publishers, Inc.

Daniel, M. C., Mondschein, M., \& de Palomo, L. (2014). The Guatemalan literacy project: Collaboration among literacy educators. In C. B. Leung, J. C. Richards, C. A. Lassonde (Eds.), International collaborations in literacy research and practice (pp. 199-220). Charlotte, NC: Information Age Publishing.

Daniel, M. C. (2010). La Preparación del maestro: Una examinación de las voces de los capacitadores que enseñan en las escuelas normales de Guatemala. GIST Education and Learning Research Journal, 4 (1), 127-137.

Darder, A. (1998). Freire and education. Routledge.

Faundez, A. (2001). Learning to question: A pedagogy of liberation. In A. M. Araújo Freire \& D. Macedo (Eds.). The Paulo Freire Reader (pp. 186-230). New York, NY: Continuum International Publishing Group.

Freire, P. (2002). Pedagogy of the Oppressed. New York, NY: Continuum International Publishing Group.

Gay, G. (2010). Culturally responsive teaching: Theory, research, and practice. New York, NY: Teachers College Press.

Gathercoal, F. (2004). Judicious Discipline. San Francisco, CA: Caddo Gap Press.

Giroux, H. A. and Robbins, C.G. (2006). Theories of reproduction and resistance in the new sociology of education: Toward a critical theory of schooling and pedagogy for the opposition. New York, NY: Routledge.

Glaser, B. G., \& Strauss, A. L. (1967). The discovery of grounded theory: Strategies for qualitative research. New York, NY: Routledge.

González, N., Moll, L. \& Amanti, C. (2005). Funds of knowledge for teaching in Latino households. Lawrence Erlbaum Associates.

Guadarrama, I. (2013). The teaching profession in Guatemala at the crossroads: Students fight against neo-liberal policies. https://upsidedownworld.org/news-briefs/newsbriefs\%20news-briefs/the-teaching-profession-in-guatemala-at-the-crossroadsstudents-fight-against-neoliberal-policies/ 
Guatemala's Ministry of Education. (2014). Informe Departamental y Municipal de Primaria. Guatemala City, Guatemala: General Office of Evaluation and Educational Research,

Hawkins, M, \& Norton, B. (2009). “Critical Language Teacher Education”. In Cambridge Guide to Second Language Teacher Education, Anne Burns \& Janet C. Richards (Eds.). (pp.30-39). New York, NY: Cambridge University Press.

Langley, G. J., Moen, R. O., Nolan, K. M., Norman, C. L., \& Provost, L.P. (2009). The improvement guide: A practical approach to enhancing organizational performance. San Francisco, CA: Jossey-Bass.

Leech, N.L. \& Onwuegbuzie, A. J. (2007). An array of qualitative data analysis tools: A call for data analysis triangulation. School Psychology Quarterly, 22(4), 557-584. DOI: $10.1037 / 1045-3830.22 .4 .557$

Norton, B., \& Toohey, R. (Eds.). (2004). Critical pedagogies and language learning. Cambridge, England: Cambridge University Press.

Orozco, M., \& Valdivia, M. (2017). Educational challenges in Guatemala and consequences for human capital and development. https://www.thedialogue.org

Rodriguez, A. D. (2013). Bilingual and ESL pre-service teachers learn about effective instruction for ELLs through meaningful collaboration. GIST-Education and Learning Research Journal, 7: 12-34.

Russell, J. L., Bryk, A. S., Dolle, D. R., Gómez, L. M., Le Mahieu, P. G., \& Grunow, A. (2017). A framework for the initiation of networked improvement communities. Teachers College Record, 119(5), 1-36.

Serrat, O. (2009). The five whys technique. Knowledge Solutions. https://www.adb.org.

Shakman, K., Bailey, J., \& Breslow, N. (2017). A primer for continuous improvement in schools and districts. https://www.tifcommunity.org

Stake, R. E. (2000). Case studies. In N.K. Denzin \& Y.S. Lincoln (Eds.). Handbook of qualitative research (2nd. ed., pp. 435-454). Newbury Park, CA: Sage.

Taylor, C. (2014). Seeds of freedom: Liberating education in Guatemala. Boulder, CO: Paradigm Publishers.

Verhoeven, L. \& Durgunoglu, A. Y. (1998). Perspectives on literacy development in multilingual contexts. In L. Verhoeven \& A. Durgunoglu (Eds.). Literacy Development in a multilingual context: Cross-cultural perspectives. Aydin (pp. ixxvii). New York, NY: Routledge.

Vygotsky, L. (2002). Pedagogy of the oppressed. 30th Anniversary Ed. New York, NY: Continuum International Publishing Group. 


\section{Authors}

${ }^{*}$ Mayra C Daniel is Professor Emerita at Northern Illinois University, De Kalb, IL, United States. Her research focuses on the preparation of culturally sensitive educators in the United States and Latin America.

ORCID: https://orcid.org/0000-0003-2702-0071

Teresa Wasonga is Professor at Northern Illinois University in the Department of Educational Leadership, Psychology, and Foundations, De Kalb, IL, United States. She is the founder of a secondary school for girls from poor rural areas in Kenya.

ORCID: https://orcid.org/0000-0002-2444-0559

Ximena Burgin is an Assistant Professor at Northern Illinois University, De Kalb, IL, United States. Her research relates to the role of multiculturalism in classroom instruction and evaluation.

ORCID: https://orcid.org/0000-0002-3494-569X

How to reference this article: Daniel, M. C., Wasonga, T., \& Burgin, X. (2021) Transforming an Educational Community in Guatemala Using the Plan Do Study Act Cycle. GIST - Education and Learning Research Journal, 23, 151-168. https://doi.org/10.26817/16925777.1053 